\title{
角形鋼管柱を有する鋼構造立体骨組の必要柱梁耐力比に及ぼす 保有水平耐力の影響
}

\section{EFFECTS OF HORIZONTAL LOAD BEARING CAPACITY ON REQUIRED COLUMN OVERDESIGN FACTOR OF 3D STEEL MOMENT FRAMES WITH SQUARE TUBE COLUMNS}

\author{
陳 逸 鴻*, 聲高 裕 治**, 吹田 啓一郎*** \\ Iathong CHAN, Yuii KOETAKA and Keiichiro SUITA
}

\begin{abstract}
This paper presents a numerical study on 3D steel moment frames with square tube columns. The major parameters are column overdesign factor, horizontal load bearing capacity, shape of frames and input direction of ground motion. From the analysis, it is revealed that the relationships between cumulative plastic deformation of columns and column overdesign factor, with the similar horizontal load bearing capacity, are not affected by the shape of frames and input direction of ground motion. The required column overdesign factor to keep the damage of columns below the limit of plastic deformation is proposed under the reliability index of 2 .
\end{abstract}

Keywords : 3D Steel M oment F rame, Square Tube Columns, Time H istory Response Analysis, Column O verdesign Factor, Input Direction of G round M otion, Horizontal Load Bearing Capacity 鋼構造立体骨組, 角形鋼管柱, 時刻歴応答解析, 柱梁耐力比, 入力方向, 保有水平耐力

\section{1. 序}

大地震時に構造物の耐震安全性を高めるためには，損傷が特定層 に集中する部分層崩壊機構より，梁や接合部パネルが先行して降伏 する全層崩壊機構を形成することが望ましい 1),2)，そのため，柱に冷 間成形角形鋼管を用いた鋼構造骨組の耐震規定には柱梁耐力比の制 限值が設けられている。例えば，許容応力度等計算ルート 3 では， 柱の鋼種が STKR の場合は最上層柱頭と最下層柱脚を除くす心゙ての 節点で， $\mathrm{BCP}$ または BCRの場合は屋上層を除くすべてのフロアレ ベルで，それぞれ柱梁耐力比を 1.5 以上とすることが規定されてい $ろ^{3), 4}$.

前報 5) では角形鋼管柱を有する鋼構造立体骨組を対象に，骨組の 層数や平面形状, 入力地震動の種類, 入力レベル, 入力方向をパラ メータとした時刻歷応答解析を行い，柱の損傷を必要值以下に抑え るための柱梁耐力比の必要值について検討した。ただし，検討骨組 の保有水平耐力については原設計のまま，特に調整を行わなかった ため，終局ベースシヤー係数が構面方向で $0.40 \sim 0.50,45^{\circ}$ 方向で $0.55 \sim 0.70$ となっており, 骨組や入力方向によって様々な值となっ ていた．部材の塑性変形応答は骨組の保有水平耐力が大きくなると 減少し，これに伴って必要な柱梁耐力比が変化すると考えられるた め, 必要柱梁耐力比に及ぼす骨組の保有水平耐力の影響についての 検討は文献 5) では不十分である.

鋼構造骨組の必要柱梁耐力比に関する既往の研究は, 前報 ${ }^{5)}$ に詳
しく述べている。それらのうち骨組の保有水平耐力と部材の損傷に ついて検討しているものとして，長谷川・山内 ${ }^{6)}$ と酒井・小川 ${ }^{7)} の$ 研究が挙げられる. 長谷川・山内 $\left.{ }^{6}\right)$ は中低層鋼構造骨組に対して, 骨組のベースシヤー係数が小さくなるにつれて, 部材の必要塑性変 形能力が大きくなることを明らかにしている．また，酒井・小川7) は中低層鋼構造骨組に対して特定層の変形集中を抑制するために必 要な柱梁耐力比を地震動の入力レベル, 直交 2 方向の梁の耐力比, 構造特性係数相当值の関数として導いている. しかしながら, 長谷 川らの研究はベースシヤー係数と部材の必要塑性変形能力について 定量的な検討を行っておらず，小川らの研究では魚骨骨組を用いて いるため, 文献 5) で指摘したような個々の部材の損傷の差異やフロ ア内の柱梁耐力比のばらつきによる影響を確認することができない.

そこで，本論文では前報 ${ }^{5)}$ に引き続き，骨組の耐力と部材の損傷 分布との関係を検討寸るために，骨組の保有水平耐力を新たなパラ メータとして加え，立体骨組モデルによる数值解析を入力レベル一 定の条件下で実施する。さらに，広範な解析結果を統計的手法によっ て分析し，保有水平耐力と柱の幅厚比に応じて柱の損傷を保有性能 以下に留めるために必要な節点ごとの柱梁耐力比の評価方法を提案 する.

\section{2. 解析パラメータ}

解析方法は前報 ${ }^{5)}$ と同様で, 各部材を線材に置換し, 各層床に剛

\footnotetext{
* 京都大学大学院建築学専攻 博士後期課程 - 修士 (工学

** 京都大学大学院建築学専攻 准教授. 博士 (工学)

Grad. Stud., Dept. of Architecture and Architectural Engineering, Kyoto Univ., M.Eng.

*** 京都大学大学院建築学専攻 教授. 博士 (工学) 


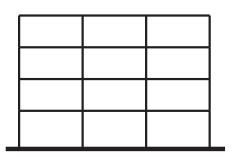

(a) 4-story

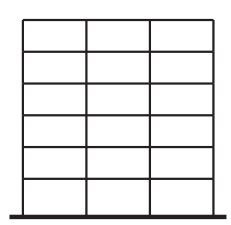

(b) 6-story

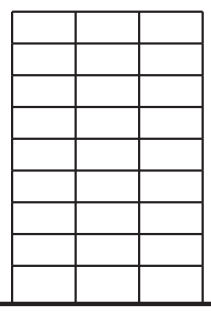

(c) 9-story

Fig.1 Elevations of frames (unit: meter)

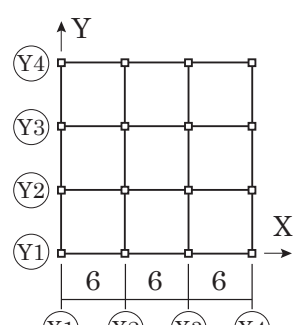

(X1) X2 X3

(a) $6-6-3 A$

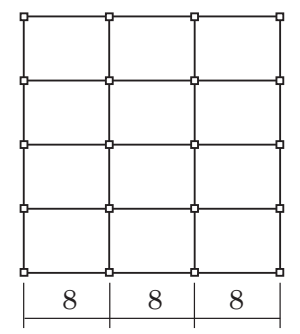

(b) 6-8-3

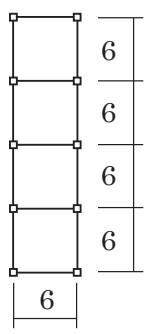

(c) 6-6-1

Fig.2 Floor plans of frames (unit: meter)

Table1 Vibration characteristic coefficients and the first natural periods of frames

\begin{tabular}{|c|c|c|}
\hline Number of stories & $R_{T}^{3)}$ & $\begin{array}{c}\text { The 1st natural period } \\
\text { (unit: second) }\end{array}$ \\
\hline 4 & 1.00 & 0.393 \\
\hline 6 & 1.00 & 0.585 \\
\hline 9 & 0.959 & 0.873 \\
\hline
\end{tabular}

Table2 Cross-sections of beams and columns in 4-story 6-6-3A

\begin{tabular}{|c|c|c|c|c|}
\hline \multirow{2}{*}{ Storey } & \multirow{2}{*}{ Frame } & \multicolumn{3}{|c|}{ Sections } \\
\hline & & \multicolumn{2}{|r|}{ Columns } & Beams \\
\hline \multirow{4}{*}{4} & $\mathrm{X} 1, \mathrm{X} 4$ & Exterior & $\square-350 \times 350 \times 9$ & \multirow{2}{*}{$\mathrm{H}-346 \times 174 \times 6 \times 9$} \\
\hline & $\mathrm{Y} 1, \mathrm{Y} 4$ & Interior & \multirow{2}{*}{$\square-400 \times 400 \times 9$} & \\
\hline & $\mathrm{X} 2, \mathrm{X} 3$ & Exterior & & \multirow{2}{*}{$\mathrm{H}-496 \times 199 \times 9 \times 14$} \\
\hline & Y2,Y3 & Interior & $\square-400 \times 400 \times 12$ & \\
\hline \multirow{4}{*}{3} & $\mathrm{X} 1, \mathrm{X} 4$ & Exterior & $\square-350 \times 350 \times 9$ & \multirow{2}{*}{$\mathrm{H}-446 \times 199 \times 8 \times 12$} \\
\hline & $\mathrm{Y} 1, \mathrm{Y} 4$ & Interior & \multirow{2}{*}{$\square-400 \times 400 \times 12$} & \\
\hline & $\mathrm{X} 2, \mathrm{X} 3$ & Exterior & & \multirow{2}{*}{$\mathrm{H}-496 \times 199 \times 9 \times 14$} \\
\hline & $\mathrm{Y} 2, \mathrm{Y} 3$ & Interior & $\square-400 \times 400 \times 16$ & \\
\hline \multirow{4}{*}{2} & $\mathrm{X} 1, \mathrm{X} 4$ & Exterior & $\square-350 \times 350 \times 9$ & \multirow{2}{*}{$\mathrm{H}-446 \times 199 \times 8 \times 12$} \\
\hline & $\mathrm{Y} 1, \mathrm{Y} 4$ & Interior & \multirow{2}{*}{$\square-400 \times 400 \times 12$} & \\
\hline & $\mathrm{X} 2, \mathrm{X} 3$ & Exterior & & \multirow{2}{*}{$\mathrm{H}-500 \times 200 \times 10 \times 16$} \\
\hline & $\mathrm{Y} 2, \mathrm{Y} 3$ & Interior & $\square-400 \times 400 \times 19$ & \\
\hline \multirow{4}{*}{1} & $\mathrm{X} 1, \mathrm{X} 4$ & Exterior & $\square-350 \times 350 \times 12$ & \multirow{2}{*}{$\mathrm{H}-450 \times 200 \times 9 \times 14$} \\
\hline & $\mathrm{Y} 1, \mathrm{Y} 4$ & Interior & \multirow{2}{*}{$\square-400 \times 400 \times 12$} & \\
\hline & $\mathrm{X} 2, \mathrm{X} 3$ & Exterior & & \multirow{2}{*}{$\mathrm{H}-600 \times 200 \times 11 \times 17$} \\
\hline & Y2,Y3 & Interior & $\square-450 \times 450 \times 19$ & \\
\hline
\end{tabular}

\begin{tabular}{|c|c|c|c|}
\hline \multicolumn{2}{|c|}{} & Beams & Columns \\
\hline \multirow{2}{*}{$e_{e} D_{s}^{\mathrm{A}}$} & 0.50 & $\boldsymbol{\Delta}$ & $\mathbf{\square}$ \\
\cline { 2 - 4 } & 0.25 & $\triangle$ & $\square$ \\
\hline
\end{tabular}

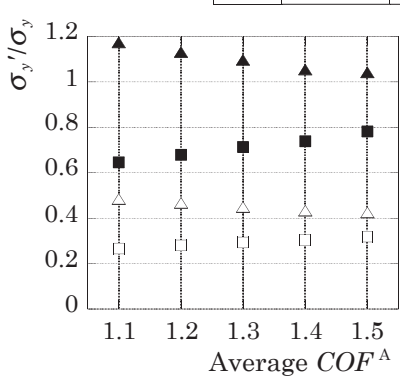

(a) Cases of input direction of 0 degrees $\quad$ of 45 degrees

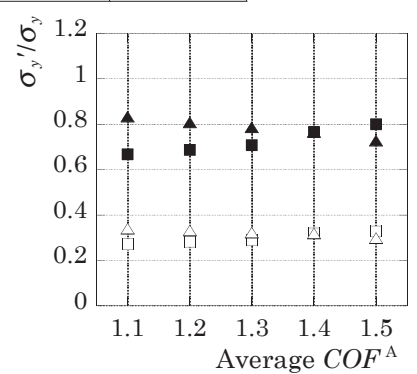

(b) Cases of input direction (4-story 6-6-3A)
床仮定を適用した立体骨組モデルを用いる．部材の両端に MS 要素 ${ }^{5}$ を配置することで弾塑性挙動を表現する。ただし，接合パネルと幾 何学的非線形性は考慮しない。骨組に関するパラメータと入力地震 動に関するパラメータは以下のものを取り上げる.

\section{1 対象骨組}

本論文では，前報 ${ }^{5)}$ で検討した 10 種類の骨組から，代表的なもの として 4 層 6-6-3A，6 層 6-6-3A，9 層 6-6-3A，部材耐力分布 のばらつきが比較的に大きいものとして 4 層 6-8-3, 直交 2 方向の スパン数が異るものとして 4 層 6-6-1 と 9 層 6-6-1 の合計 6 種類 を取り上げる。骨組の軸組図を図 1 に, 平面形状を図 2 に示す。一 例として，4層 6-6-3A 骨組の部材断面を表 2 に示す.

骨組のパラメータは層数と平面形状の他に, 見かけの柱梁耐力比 $C O F^{\mathrm{A}}$ と見かけの構造特性係数相当值 ${ }_{e} D_{s}^{\mathrm{A}}$ を採用する. $C O F^{\mathrm{A}}$ は前 報 ${ }^{5)}$ と同様，節点ごとの入力方向に投影した梁の全塑性曲げモーメ ントに対する柱の全塑性曲げモーメントの比率として定義する.

また，見かけの構造特性係数相当值 ${ }_{e} D_{s}{ }^{\mathrm{A}}$ は, 終局ベースシヤー係 数 $C_{b u}{ }^{\mathrm{A}}$ と振動特性係数 $R_{T}$ を用いて (1) 式で定義する.

$$
{ }_{e} D_{s}{ }^{\mathrm{A}}=C_{b u}{ }^{\mathrm{A}} / R_{T}
$$

ここで, $C_{b u}{ }^{\mathrm{A}}$ は $A_{i}$ 分布に基づく水平力を静的に作用させ，入力方向 に投影した最大の層間変形角が $0.01 \mathrm{rad}$ に達したときの入力方向の ベースシャー係数としている． $R_{T}$ は現行の耐震基準 ${ }^{3)}$ に基づき，第 2 種地盤を想定して算定する。ただし， $R_{T}$ の算定に用いる 1 次固有 周期は建物の高さに 0.03 を乗じた值とする. 算定した $R_{T}$ と算定に 用いた 1 次固有周期を表 1 に示す。 また, 固有值解析により得られ

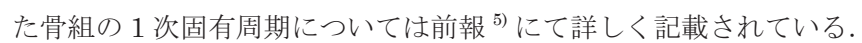

$C O F^{\mathrm{A}}$ と ${ }_{e} D_{s}{ }^{\mathrm{A}}$ 值の検討範囲については, 骨組全体の $C O F^{\mathrm{A}}$ の平均 值を $1.0 \sim 1.5$ 程度, ${ }_{e} D_{s}{ }^{\mathrm{A}}$ 值を $0.25 \sim 0.50$ とする. それぞれの入力 方向における骨組の $C O F^{\mathrm{A}}$ と ${ }_{e} D_{s}^{\mathrm{A}}$ 值が指定值になるように，原設計 の部材断面のままで，試行錯誤で柱と梁の降伏応力を調整している. 一例として, 4 層 6-6-3 の調整後の降伏応力 $\sigma_{y}{ }^{\prime}$ と元設計の降伏応 力 $\sigma_{y}\left(=235 \mathrm{~N} / \mathrm{mm}^{2}\right)$ の比を図 3 に示す.

\section{2 入力地震動}

入力地震動のパラメータは, 入力方向を $0^{\circ}$ ( $\mathrm{X}$ 方向), $45^{\circ}, 90^{\circ}(\mathrm{Y}$ 方向）の 3 種類，入力波を BCJ L2，El Centro NS，JMA Kobe NS の 3 種類とする。前報では，入力レベルを損傷に寄与する地震入力 エネルギーの速度換算值 $V_{\mathrm{dm}}$ によって変化させ， 2 次設計レベルに相 当する $1.5 \mathrm{~m} / \mathrm{s}$ とその 1.5 倍の $2.25 \mathrm{~m} / \mathrm{s}$ の 2 種類とした. $V_{\mathrm{dm}}$ の増大 に伴い各部材の損傷が増加するが， $V_{\mathrm{dm}}$ の大小によって部材ごとの損 傷の分布傾向が変化しない ${ }^{5)}$ ため, 本論文では 2 次設計レベルに相 当する $V_{\mathrm{dm}}=1.5 \mathrm{~m} / \mathrm{s}$ の場合だけを対象とし， $V_{\mathrm{dm}}$ 值が一定となるよう に地震動の地動加速度を調整している。

\section{3. 解析結果と考察}

\section{3. $1{ }_{e} D_{s}^{\mathrm{A}}$ 値の影響}

見かけの構造特性係数相当值 ${ }_{e} D_{s}^{\mathrm{A}}$ の違いがフロアレベルおよび部 材ごとの損傷分布に与える影響を確認するために, ${ }_{e} D_{s}{ }^{\mathrm{A}}$ 值が 0.25 と 0.50 の 4 層 6-6-3A に対して El Centro NS を入力したときの時刻 歴応答解析結果について検討する。ここでは一部の骨組の結果だけ を示すが，各骨組の損傷分布における ${ }_{e} D_{s}{ }^{\mathrm{A}}$ 值の影響は，層数，平面 形状, 入力地震動によらず, ほぼ同様の傾向が確認された. 

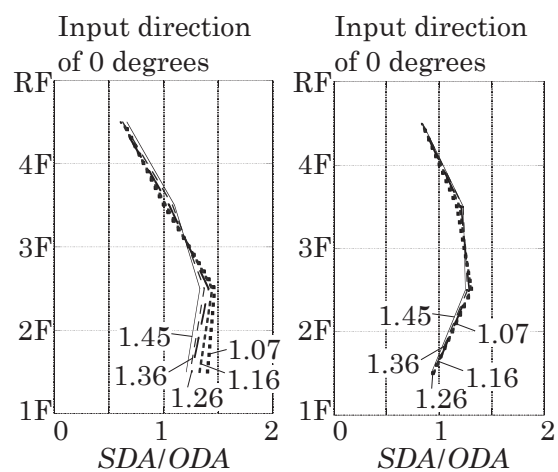

Input direction $\mathrm{RF}_{\mathrm{f}}$ of 45 degrees

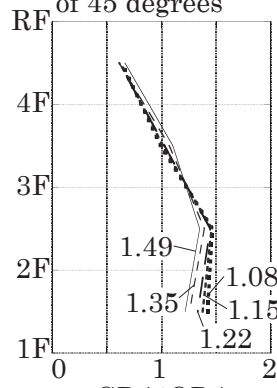

$S D A / O D A$
(a) $D_{s}^{\mathrm{A}}=0.25$
Input direction

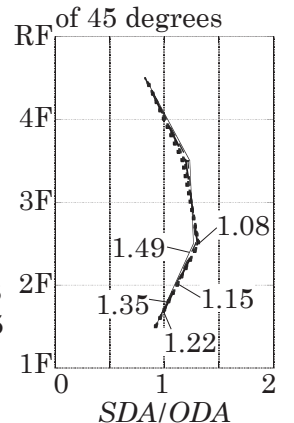

(b) ${ }_{e} D_{\mathrm{s}}^{\mathrm{A}}=0.50$

Fig.4 Maximum story drift angles (4s663A)

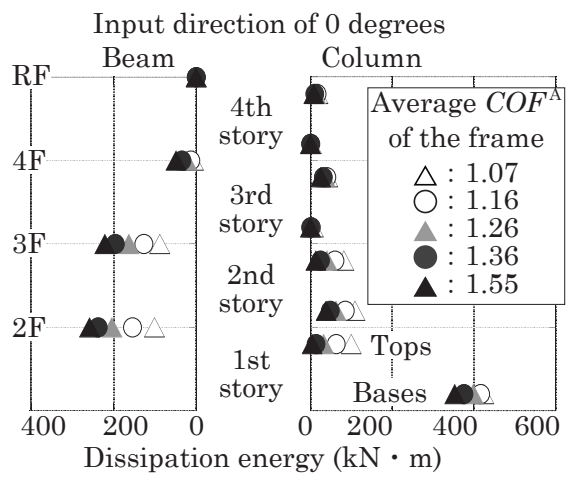

Input direction of 45 degrees

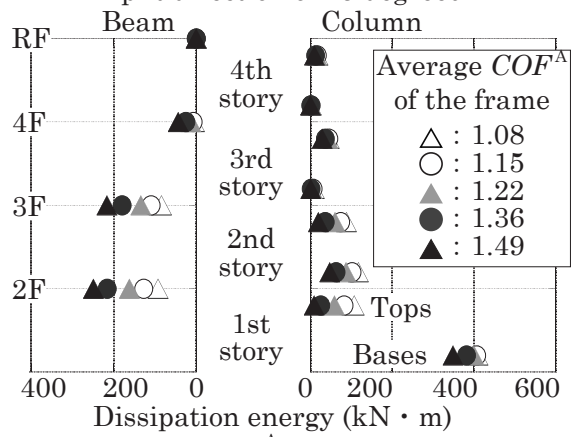

(a) ${ }_{e} D_{s}^{\mathrm{A}}=0.25$

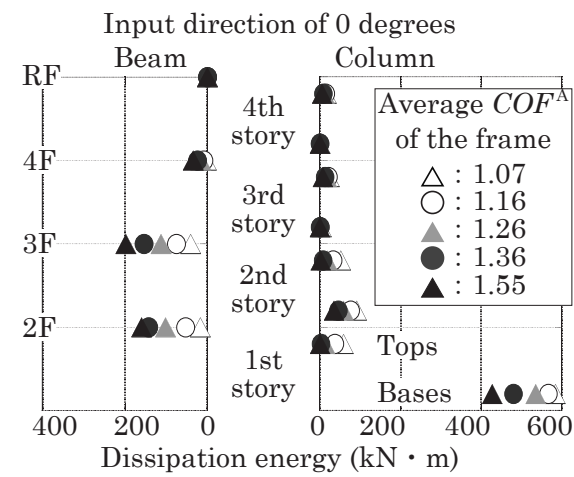

Input direction of 45 degrees

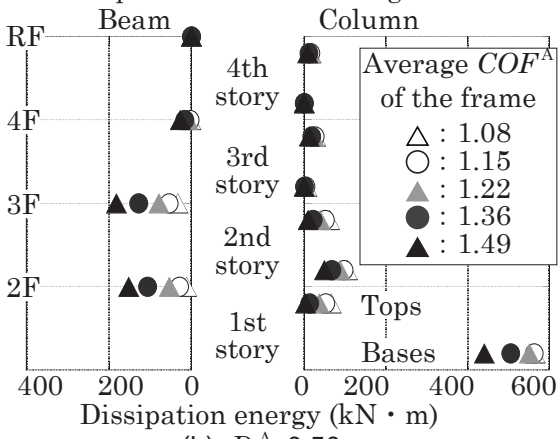

(b) ${ }_{e} D_{s}^{\mathrm{A}}=0.50$

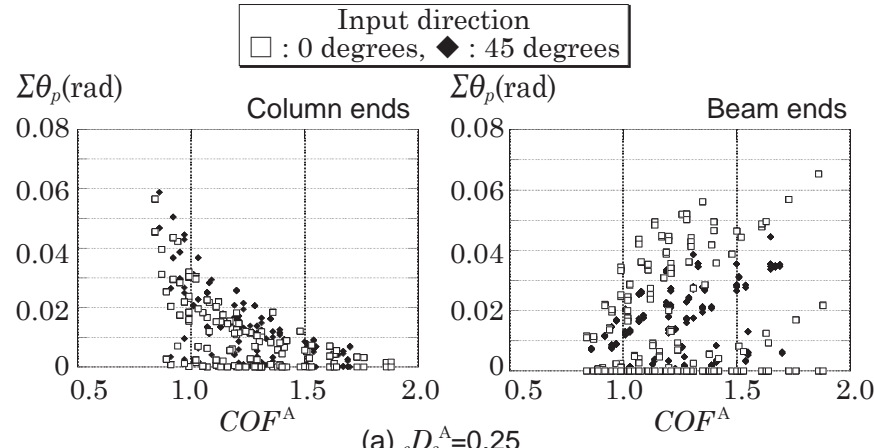

(a) ${ }_{e} D_{s}^{\mathrm{A}}=0.25$

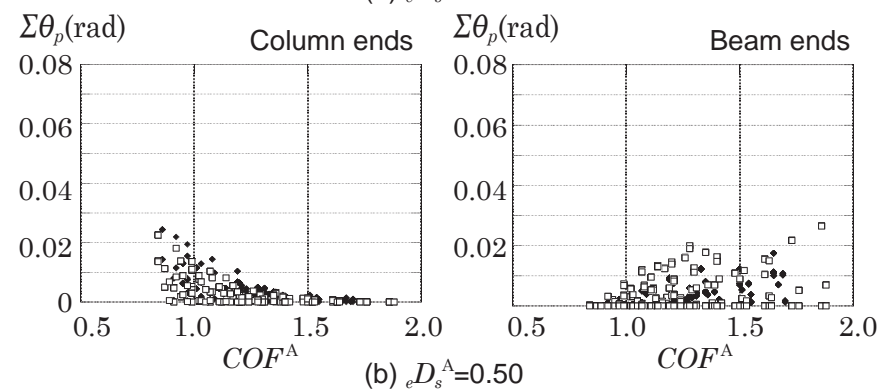

Fig.6 $\Sigma \theta_{p}-C O F^{\mathrm{A}}$ relations $(4 \mathrm{~s} 663 \mathrm{~A})$

まず，フロアレベルの損傷分布を検討するために，図 4 に最大層 間変形角 $(S D A)$ と最大全体変形角 $(O D A)$ の比の高さ方向分布を示寸. 図中に示寸数字は各骨組の最上層柱頭と最下層柱脚を除くすべての 節点における見かけの柱梁耐力比 $C O F^{\mathrm{A}}$ の平均值である. 図 5 にフ ロアごとの部材別消費エネルギーの総和を示している.

図 4 より, ${ }_{e} D_{s}{ }^{\mathrm{A}}$ 值が 0.25 の場合, 1 層と 2 層の層間変形角が上層 部より大きく, 骨組の $C O F^{\mathrm{A}}$ の平均值が大きくなるにつれ 1 層と 2 層の層間変形角が減少する。一方で， ${ }_{e} D_{s}{ }^{\mathrm{A}}$ 值が 0.50 の場合は，2 層 と 3 層の層間変形角が大きいが層ごとの差が小さく, $C O F^{\mathrm{A}}$ の平均
值によって層間変形角の分布が変化しない。また，図 5 より, ${ }_{e} D_{s}{ }^{\mathrm{A}}$ 值が大きくなると, 1 層柱脚以外の部材端の消費エネルギーが減少し, 減少した分のエネルギーが 1 層柱脚に移行することがわかる.

${ }_{e} D_{s}^{\mathrm{A}}$ 值が増大寸るにつれて, 図 4 では上層部の最大層間変形角が 大きくなるのに対して, 図 5 では 1 層柱脚の消費エネルギーだけ増 加している. このように, 図 4 と図 5 の傾向が異なっているよう に見える.これは，本論文では部材の降伏応力のみ変更することで ${ }_{e} D_{s}^{\mathrm{A}}$ 值を調整しており,${ }_{e} D_{s}{ }^{\mathrm{A}}$ 值の大きい骨組では部材の降伏耐力や 弾性限变形も大きいことに起因している。すなわち, 弾性変形を含 んだ最大層間変形角では図 4 に示すように, ${ }_{e} D_{s}^{\mathrm{A}}$ 值が増大寸ると上 層部の最大変形角が増えるが，その大部分は弾性変形であり，塑性 変形による消費エネルギーでは図 5 に示すように， 1 層柱脚の消費 エネルギーだけが増加し，それ以外の部材端における消費エネルギー が減少する.

次に, 部材レベルの損傷分布を検討するために, 図 6 に節点ごと の等価な累積塑性回転角 $\Sigma \theta_{p}$ と見かけの柱梁耐力比 $C O F^{\mathrm{A}}$ の関係を 示す。ここで，等価な累積塑性回転角 $\Sigma \theta_{p}$ は各部材端の曲げによる 消費したエネルギーを長期軸力を考慮した全塑性モーメントで除し た值である. 図 6 には 1 層柱脚の結果を含んでいないため, 図 5 に おける 1 層柱脚以外の結果と同様に, ${ }_{e} D_{s}{ }^{\mathrm{A}}$ 值が増大寸ると各部材端 の $\Sigma \theta_{p}$ が減少する. 前報では, 梁の全塑性モーメントを原設計のま まとしているため, $45^{\circ}$ 方向の ${ }_{e} D_{s}{ }^{\mathrm{A}}$ 值が構面方向の約 $\sqrt{2}$ 倍になり, その結果, $45^{\circ}$ 方向入力時の $\Sigma \theta_{p}$ が構面方向入力時より小さくなっ ている ${ }^{5}$. これに対して, 本論文では, 各入力方向における骨組の ${ }_{e} D_{s}^{\mathrm{A}}$ 值が同程度になるように柱と梁の降伏応力をともに調整してい るため, 柱の損傷分布は入力方向によらず同程度の值となる。一方で, 梁の損傷分布については， $45^{\circ}$ 方向入力の場合では直交 2 方向の梁 


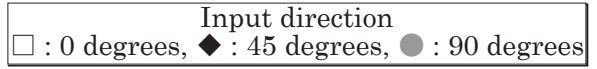

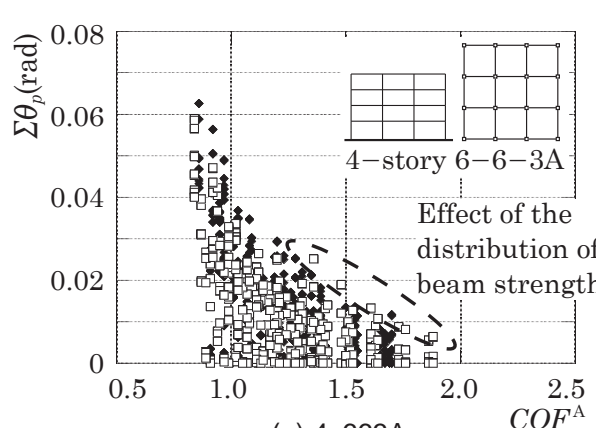

(a) $4 \mathrm{~s} 663 \mathrm{~A}$

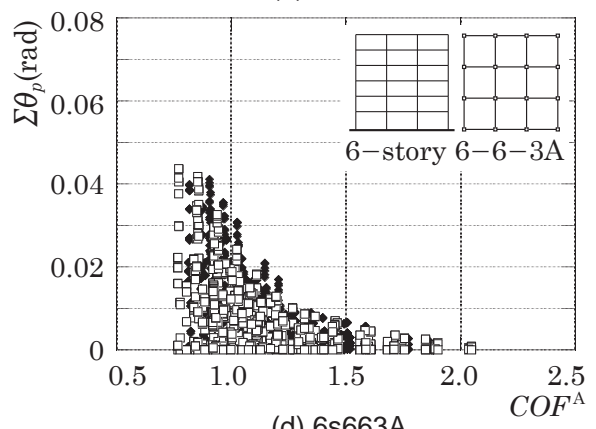

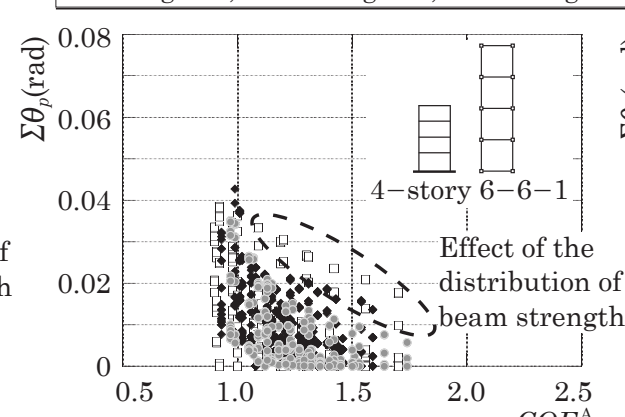

(b) $4 \mathrm{~s} 661$

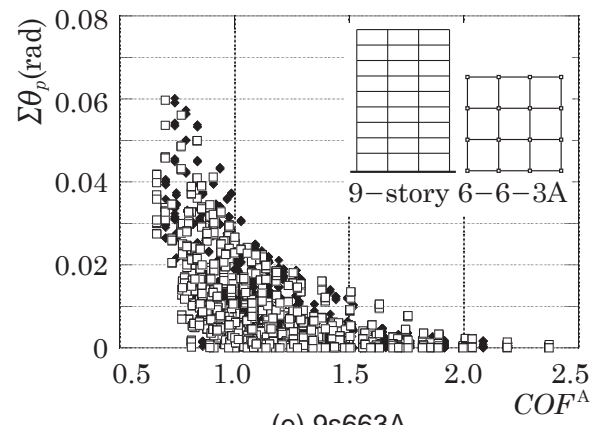

(e) $9 \mathrm{~s} 663 \mathrm{~A}$

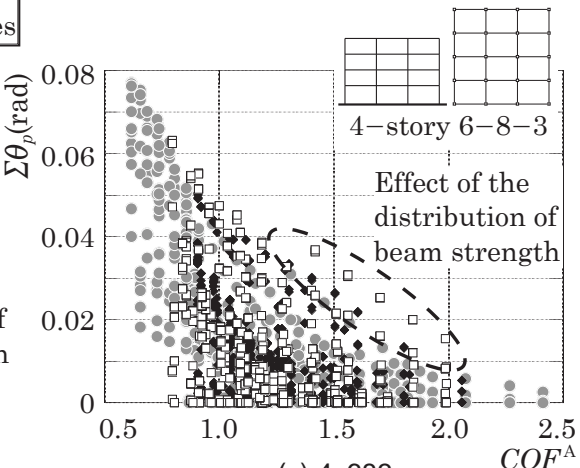

(c) $4 \mathrm{~s} 683$

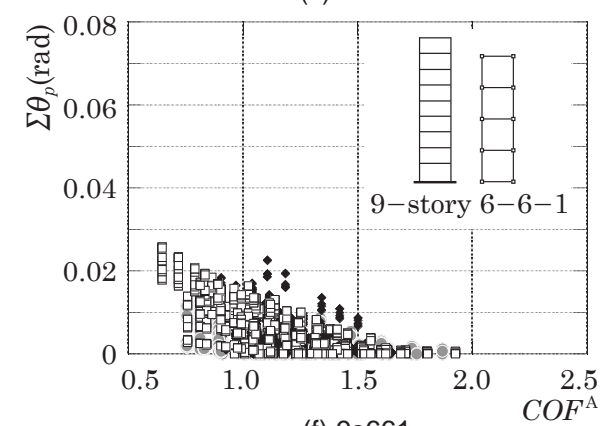

Fig.7 Columns' $\Sigma \theta_{p}-C O F^{\mathrm{A}}$ relation $\left({ }_{e} D_{s}{ }^{\mathrm{A}}=0.25\right)$

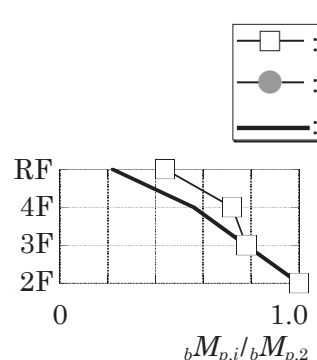

(a) $4 \mathrm{~s} 663 \mathrm{~A}$

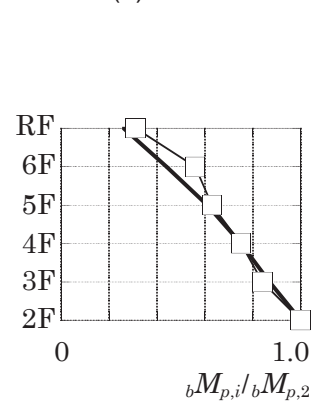

(d) $6 \mathrm{~s} 663 \mathrm{~A}$ $-\square-$ : Distribution on 0 degrees (X-axis)
- : Distribution on 90 degrees (Y-axis)
—: Optimal distribution (Eq.(2))

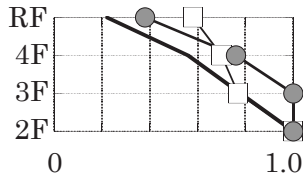

${ }_{b} M_{p, i} /{ }_{b} M_{p, 2}$

(b) $4 \mathrm{~s} 661$

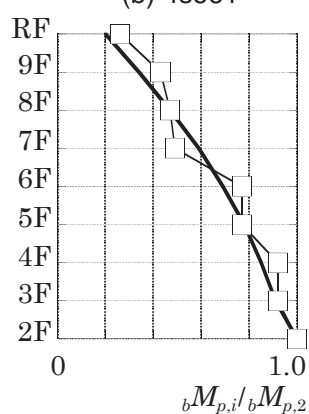

(e) $9 \mathrm{~s} 663 \mathrm{~A}$

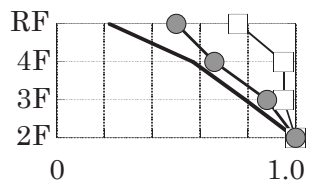

${ }_{b} M_{p, i} /{ }_{b} M_{p, 2}$

(c) 45683

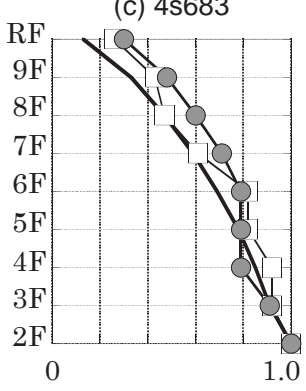

(f) $9 \mathrm{~s} 661$

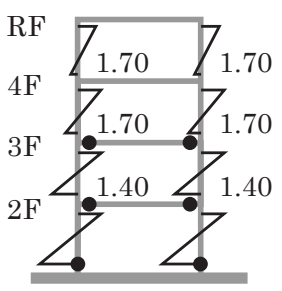

(a) Hinges formed in $3 F$ beam

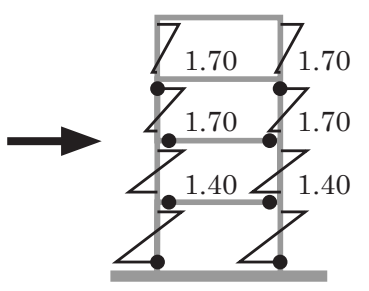

(b) Hinges formed in 3rd story column tops

Fig.9 P rogress status of plastic hinges Input direction of 0 degrees

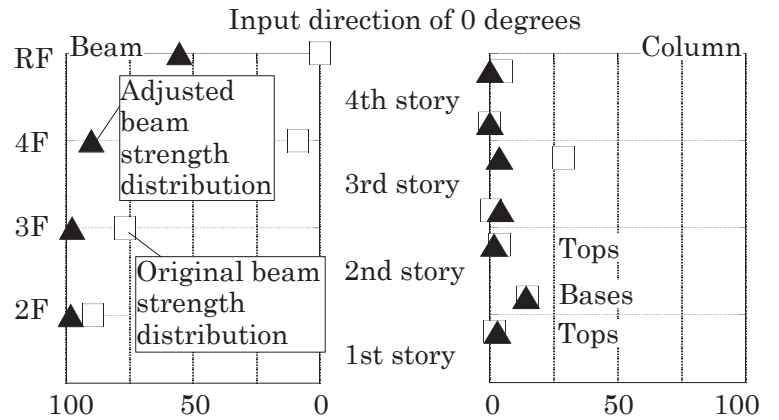

Dissipation energy $(\mathrm{kN} \cdot \mathrm{m}) \quad$ Dissipation energy $(\mathrm{kN} \cdot \mathrm{m})$

Fig.10 Sum of the members' dissipation energy (4-story 6-6-1)

Fig. 8 Distribution of the sum of beam strength per floor

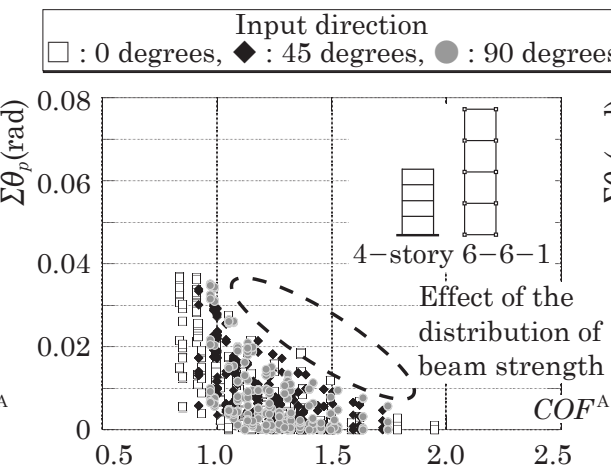

(b) 4 s661

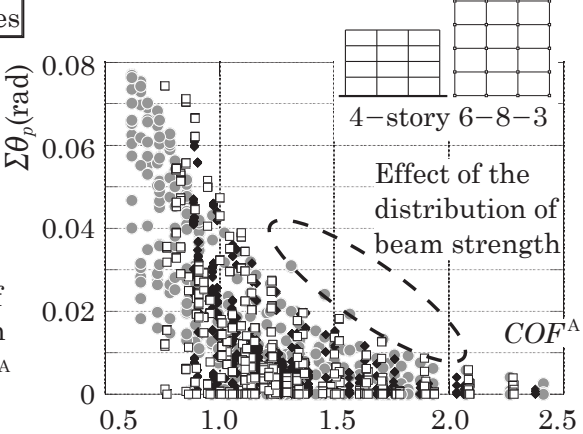

(c) 45683

(a) $4 \mathrm{~s} 663 \mathrm{~A}$

Fig.11 Columns' $\Sigma \theta_{p}$-COF ${ }^{\mathrm{A}}$ relation of frames with adjusted beam strength distribution $\left({ }_{e} D_{s}^{\mathrm{A}}=0.25\right)$ 
が損傷を分担するのに対して, 構面方向入力の場合では入力と平行 な 1 方向の梁だけに損傷が集中するため, 構面方向入力における梁 端の損傷が $45^{\circ}$ 方向入力の約 2 倍になっている.

\section{2 部材耐力分布の影響}

3.1 節では梁と柱両方の損傷について検討しているが，大地震時に 梁が先行して降伏する全層崩壊機構を形成するためには，柱の損傷 を抑える必要がある. 以下では見かけの構造特性係数相当值 ${ }_{e} D_{s}{ }^{\mathrm{A}}$ が 同程度の骨組に対して，柱端の損傷分布に及ぼす部材耐力分布の影 響を検討する，柱端の損傷分布について，図 7 に ${ }_{e} D_{s}^{\mathrm{A}}$ 值が 0.25 の場 合の等価な累積塑性回転角 $\Sigma \theta_{p}$ と見かけの柱梁耐力比 $C O F^{\mathrm{A}}$ の関係 を骨組ごとに示す，ただし，図 7 には全入力地震動の結果をまとめ て示している.

一方で小川らはすべての梁に一様な塑性変形が生じるための最適 な梁耐力分布を (2) 式で提案している ${ }^{8)}$.

$$
{ }_{b} M_{p, i}=\frac{Q_{i-1} h_{i-1}+Q_{i} h_{i}}{2}
$$

ただし, ${ }_{b} M_{p, i}$ は $i \mathrm{~F}$ の方向または $\mathrm{Y}$ 方向における全梁の全塑性モー メントの和， $Q_{i}$ は $A_{i}$ 分布に基づく $i$ 層の設計用層せん断力, $h_{i}$ は $i$ 層の階高である.

本論文では，柱梁耐力比が 1 以上で，かつフロアレベル梁耐力和 の高さ方向分布が (2) 式の分布と同様であれば，フロアレベルでみた 梁の塑性変形が同程度になるかについて検討寸る.

図 8 に $2 \mathrm{~F}$ の梁耐力和 ${ }_{b} M_{p, 2}$ を基準とした各フロアレベルの梁耐力 和 ${ }_{b} M_{p, i}$ の高さ方向分布を示す. 図 8 より, (d), (e), (f) の 3 つの骨 組では梁耐力和の高さ方向分布が (2) 式の分布と概ね同様であるのに 対して, (a), (b), (c) の骨組では梁耐力和分布が (2) 式の適正分布之 大きく異なるフロアレベルがある. 図 7 より, $C O F^{\mathrm{A}}$ が大きくなると， $\Sigma \theta_{p}$ の最大值が減少する傾向は全骨組において同様であるが，定量的 には，(a)，(b)，(c)の骨組では，破線で囲んでいる $C O F^{\mathrm{A}}$ が 1.0 2.0 の範囲で他の骨組と比べて $\Sigma \theta_{p}$ が大きくなっていることが確認でき る.このように，実際の梁耐力和分布と (2) 式の適正分布の差が大き い4 層 6-6-3A，4層 6-6-1，4層 6-8-3 の $0^{\circ}$ 方向では，同じ $C O F^{\mathrm{A}}$ に対する $\Sigma \theta_{p}$ のばらつきが大きい.

\section{3 梁耐力和の調整}

3.2 節では，フロアレベルの梁耐力和の分布と (2) 式の適正分布の 差が大きいほど, $\Sigma \theta_{p}-C O F^{\mathrm{A}}$ 関係のばらつきが大きくなることを確 認した．本節では骨組の梁耐力を調整することにより，同じ $C O F^{\mathrm{A}}$ に対する $\Sigma \theta_{p}$ のばらつきの改善を試みる.

まず，図 8(b) の 4 層 6-6-1 の $0^{\circ}$ 方向の梁耐力和分布に着目する と, (2) 式の分布と比べて, $4 \mathrm{~F} と \mathrm{RF}$ の梁耐力和が高く, 地震時には $4 \mathrm{~F}$ と $\mathrm{RF}$ より， $2 \mathrm{~F}$ と $3 \mathrm{~F}$ の梁が早期に降伏すると考えられる。 その ため, 図 9 に塑性変形の進行状況を示して, 損傷分布に及ぼす梁耐 力和分布の影響を検討する. 図 9 は $C O F^{\mathrm{A}}$ の平均值が 1.50 で, ${ }_{e} D_{s}^{\mathrm{A}}$ 值が 0.25 の 4 層 6-6-1 の $0^{\circ}$ 方向に JMA Kobe NS を入力した結 果の一部である. ただし, 部材端の曲げモーメントが長期軸力を考 慮した全塑性モーメントを超えたときに塑性ヒンジが形成されるも のとする. 図 9 中の数值は各節点の $C O F^{\mathrm{A}}$ の值である. 図 9 より, $3 \mathrm{~F}$ 梁が塑性ヒンジを形成後, 3 層柱脚の曲げモーメントが増加しな くなり，3層の反曲点高さが低下し始める。これに加え，最上層の反 曲点が常に階高の半分以下であるため, $4 \mathrm{~F}$ では $C O F^{\mathrm{A}}$ が 1.7 で大き
いにも関わらず， 3 層柱頭が $4 \mathrm{~F}$ 梁端より早く全塑性モーメントに達 する.

図 9 と同じ解析に基づき, フロアレベルの部材ごとの消費エネル ギー総和を図 10 にロ印で示す. 1 層柱脚を除いた柱端では 3 層柱頭 の消費エネルギーが最も大きく, 梁端では $2 \mathrm{~F}$ と $3 \mathrm{~F}$ に比べて $4 \mathrm{~F}$ と $\mathrm{RF}$ の消費エネルギーがかなり小さいことがわかる. 次に, 梁耐力 和分布が (2) 式の分布と同様になるように骨組の $C O F^{\mathrm{A}}$ の平均值と ${ }_{e} D_{s}{ }^{\mathrm{A}}$ 值を変化させずに，フロアレベルごとの梁の降伏応力だけを調 整した 4 層 6-6-1の結果を図 10 に印で示寸. 梁耐力和分布を調 整したム印の結果では，3F 柱頭の損傷が減少し， $4 \mathrm{~F}$ と $\mathrm{RF}$ の梁の損 傷が大幅に増加する. 梁耐力和の分布を (2) 式の分布と同様にすれば,

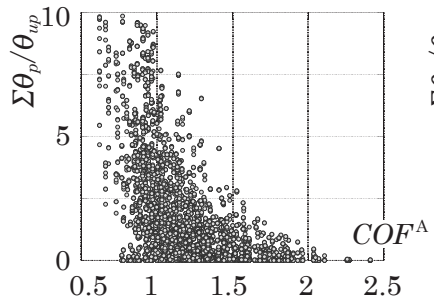

(a) FA rank

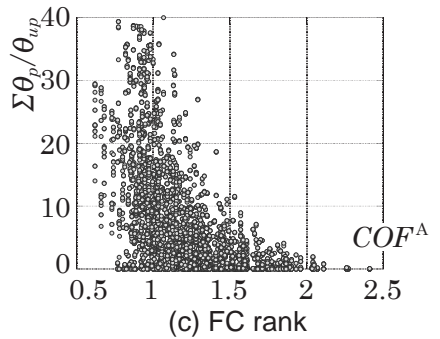

Fig.12 Damage distribution of each width-thickness ratio $\left({ }_{e} D_{s}{ }^{\mathrm{A}}=0.25\right)$

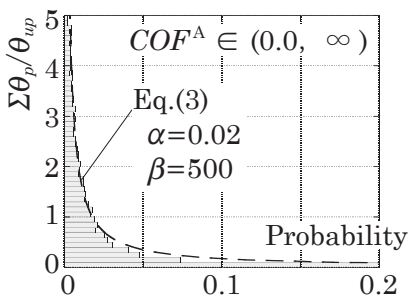

(a) Entire relation

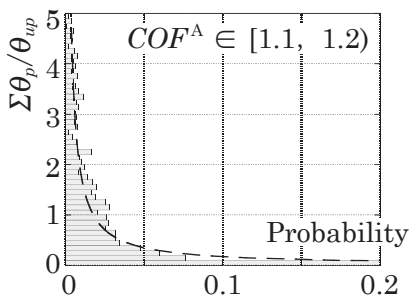

(c) Interval of [1.1, 1.2)

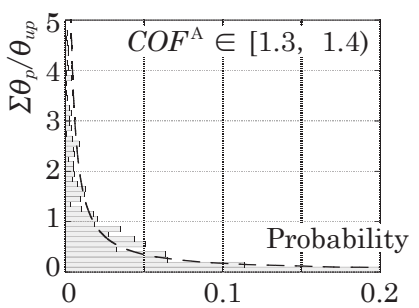

(e) Interval of [1.3, 1.4)

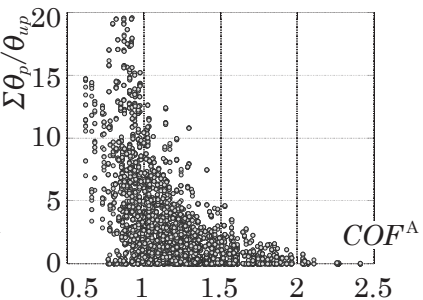

(b) FB rank

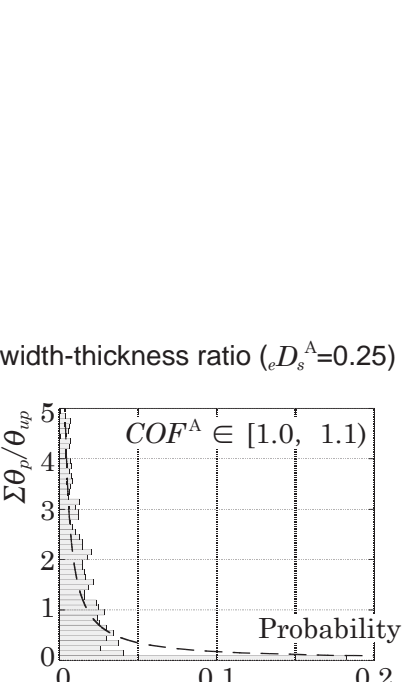

(b) Interval of $[1.0,1.1)$

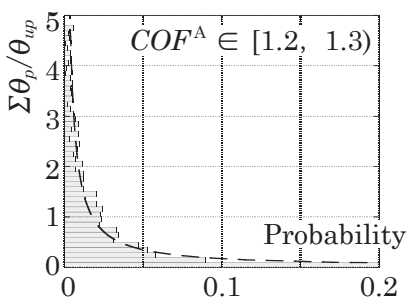

(d) Interval of [1.2, 1.3)

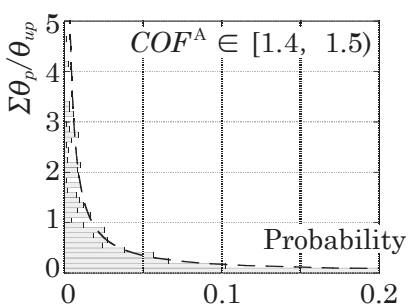

(f) Interval of $[1.4,1.5)$

Fig.13 P robability distribution for $\Sigma \theta_{p}-C O F^{\mathrm{A}}$ relation $\left({ }_{e} D_{s}^{\mathrm{A}}=0.25, \mathrm{FA}\right.$ rank) 
フロアレベルの梁の消費エネルギー分布が (2) 式の分布に近い状態と なる，消費エネルギーを全塑性モーメントで除した值である等価な 累積塑性変形角 $\Sigma \theta_{p}$ で見ると, フロアレベルにおける梁端の $\Sigma \theta_{p}$ の 和がすべての層において概衫同程度になることがわかる.

次に，各骨組の柱端の損傷分布に及ぼす梁耐力和分布の影響を検 討するために, X方向 $\left(0^{\circ}\right.$ 方向 $)$ 構面の梁耐力和分布を (2) 式の分

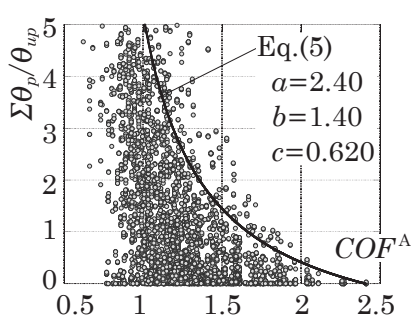

(a) ${ }_{e} D_{s}^{\mathrm{A}}=0.25$

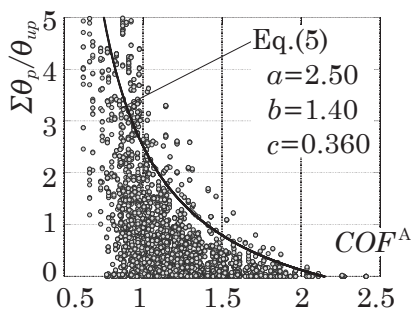

(c) ${ }_{e} D_{s}{ }^{\mathrm{A}}=0.35$

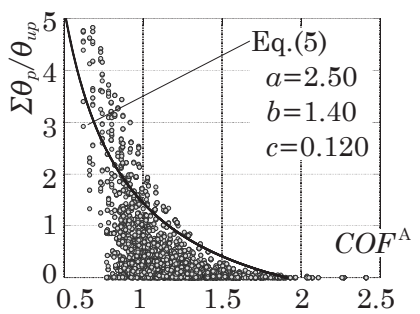

(e) ${ }_{e} D_{s}{ }^{\mathrm{A}}=0.45$

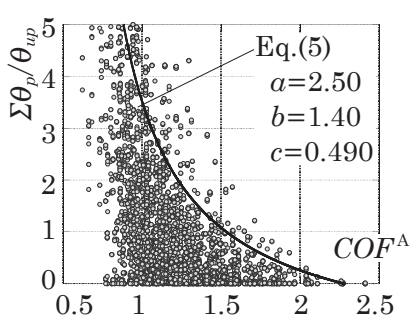

(b) ${ }_{e} D_{s}^{\mathrm{A}}=0.30$

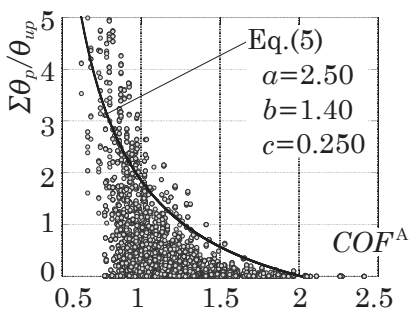

(d) ${ }_{e} D_{s}{ }^{\mathrm{A}}=0.40$

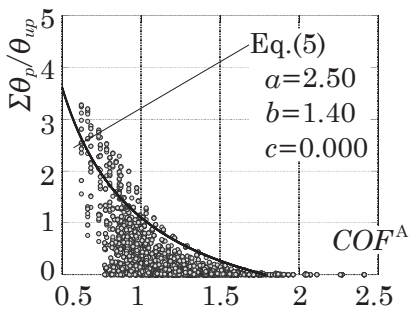

(f) ${ }_{e} D_{s}^{\mathrm{A}}=0.50$

Fig.14 Damage distributions and Envelope curves of FA rank

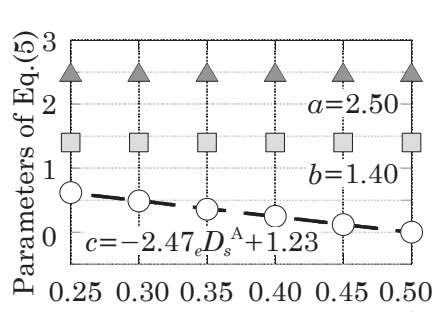

${ }_{e} D_{s}^{\mathrm{A}}$

Fig.15 Relationshipe between ${ }_{e} D_{s}^{A}$ and parameters of Eq.(5) (FA rank)

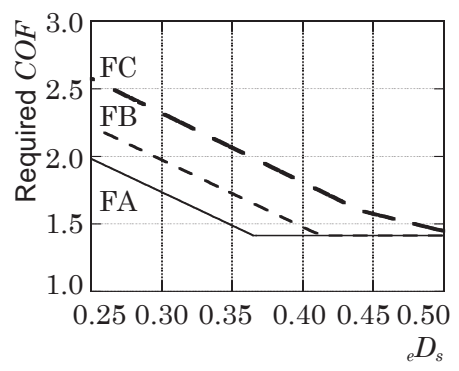

Fig.17 Required $C O F$ for each width-thickness rank
布と同様になるように調整した 4 層 6-6-3A，4 層 6-6-1，4 層 6-8-3 それぞれの $\Sigma \theta_{p}-C O F^{\mathrm{A}}$ 関係を図 11 に示す。ただし, 図 11 には ${ }_{e} D_{s}{ }^{\mathrm{A}}$ 值が 0.25 の骨組の全入力地震動に対する結果をまとめて 示寸．梁耐力和分布による影響を明確にするために，図 11 にも図 7(a), (b), (c) と同じ位置に破線を示す.

図 7(a), (b), (c) と比べ，図 11 では梁耐力の和を調整することで $\Sigma \theta_{p}$ が減少して, 破線内のプロットがほぼなくなり, 同じ $C O F^{\mathrm{A}}$ に 対する $\Sigma \theta_{p}$ のばらつきが小さくなっている. ただし, 図 11(c)の 4 層 6-8-3の 90 方向入力の結果において, 破線内に全体の分布傾 向から逸脱しているプロットがある.これは前報で報じたように, 同一フロアにおける柱梁耐力比の分布が不均等であることに起因し ている ${ }^{5)}$. 図 11 と図 7(d), (e), (f) を比較すると, 同じ $C O F^{\mathrm{A}}$ に対 する $\Sigma \theta_{p}$ の最大值分布が同程度であることがわかる．このことより， 梁耐力和分布が $(2)$ 式に従い, ${ }_{e} D_{s}^{\mathrm{A}}$ 值が同程度であれば, 柱の $\Sigma \theta_{p}$ と $C O F^{\mathrm{A}}$ の関係は骨組の層数や平面形状, 地震動の入力方向によらず, ほぼ同様な傾向を示す.

\section{4. 必要柱梁耐力比の検討 \\ 4. 1 損傷の評価指標}

3 章の考察より, 見かけの構造特性係数相当值 ${ }_{e} D_{s}^{\mathrm{A}}$ が同程度であれ ば，柱端の等価な累積塑性回転角 $\Sigma \theta_{p}$ と見かけの柱梁耐力比 $C O F^{\mathrm{A}}$ の関係は骨組の層数と平面形状, 地震動の入力方向の影響を受けに くいことが明らかになった．本章では全解析ケースで得られた柱の $\Sigma \theta_{p}$ と $C O F^{\mathrm{A}}$ の関係を一括して分析することで, 必要な柱梁耐力比 を検討する. 本論文では部材の劣化挙動を考慮していないため, 前報 ${ }^{5)}$ と同様，局部座屈によって最大曲げ耐力に至るときの塑性回転角 $\theta_{u p}$ を保有変形性能とし， $\Sigma \theta_{p}$ を $\theta_{u p}$ で除すことによって柱の損傷の程度 を表現する.

柱の幅厚比に応じて $\theta_{u p}$ が変化することを考慮し, 柱の耐力が同 じであれば幅厚比が異なっても累積塑性回転角 $\Sigma \theta_{p}$ は変化しないも のと仮定し, 幅厚比を仮想的に FA (幅厚比 33), FB (幅厚比 37), $\mathrm{FC}$ (幅厚比 48）の各ランクの限界值としたときの対応する塑性変形 能力 $\theta_{u p}$ を求める. 等価な累積塑性回転角 $\Sigma \theta_{p}$ を幅厚比ランク別の $\theta_{u p}$ で無次元化した值と $C O F^{\mathrm{A}}$ の関係を図 12 に示す.だだし, 図 12 は ${ }_{e} D_{s}^{\mathrm{A}}$ 值が 0.25 の結果で, 全骨組の 3 つの入力方向と 3 つの地震動 に対する結果をまとめて示している。 また, $C O F^{\mathrm{A}}$ に対する $\Sigma \theta_{p} / \theta_{u p}$ の最大值分布をわかりやすくするために, 図 12 の (a), (b), (c) 各図 の縦軸のスケールが異なっている.

\section{2 損傷の確率分布}

前報 ${ }^{5)}$ では信頼性指標 2 を基準に, $\Sigma \theta_{p} / \theta_{u p}-C O F^{\mathrm{A}}$ 関係の 98 パー センタイル值を必要柱梁耐力比として, その包絡線を求めた。しかし, 損傷の確率分布などについて検討していないため, 本論文では損傷 の確率分布を分析し, 包絡線の妥当性を検討する. $C O F^{\mathrm{A}}$ の主な検 討範囲 $1.0 \sim 1.5$ の間を 5 つの区間に分け, 図 12(a)の FA ランクの $\Sigma \theta_{p} / \theta_{u p}-C O F^{\mathrm{A}}$ 関係における全体および上述の区間ごとの確率分布 を図 13 に示す. 図 13(a)の全体の確率分布は (3) 式のガンマ分布の 確率密度関数と見なせる.

$$
f(x)=\frac{x^{\alpha-1} e^{-x / \beta}}{\Gamma(\alpha) \beta^{\alpha}}
$$

ただし， $\Sigma \theta_{p} / \theta_{u p}$ を(3) 式の確率変数 $x$ とし，e はネイピア数， $\alpha$ は 
ガンマ分布の形状母数, $\beta$ はガンマ分布の尺度母数, $\Gamma$ はガンマ関 数で (4) 式で与えられる.

$$
\Gamma(\alpha)=\int_{0}^{\infty} t^{\alpha-1} e^{-t} d t
$$

図 13(a)の全体の確率分布と概ね同様になるように，(3) 式の $\alpha$ と $\beta$ を同定する。同定した結果を図 13 に破線で示す。図 13 より，(a) 図の全体の確率分布から同定した (3) 式の結果が他の区間の分布とほ ぼ同様であることがわかる. 図 13 のガンマ分布に対して, 標準偏差 の 2 倍と平均值との和を上限と寸る累積分布確率は約 $98.2 \%$ であり, 前報で採用した 98 パーセンタイル值と同程度となることが明らかに なった。

\section{3 必要柱梁耐力比の包絡線}

4.2 節の結果から, 本論文でも信頼性指標 2 を基準にとり, 全体に おいても各区間においてもプロットが 98\% 以上包含されるように (5) 式に示寸関数を用いて必要柱梁耐力比の包絡線を求める. ただし, $a$, $b, c$ は (5) 式の形状を決定する係数である.

$$
C O F_{\mathrm{A}}=\frac{a}{\Sigma \theta_{p} / \theta_{u p}+b}+c
$$

図 14 に ${ }_{e} D_{s}^{\mathrm{A}}$ 值別の $\mathrm{FA}$ ランクの $\Sigma \theta_{p} / \theta_{u p}-C O F^{\mathrm{A}}$ 関係を示す. ${ }_{e} D_{s}^{\mathrm{A}}$ 值が 0.25 の FA ランクの結果に対して, 上述のように全体およ び $C O F^{\mathrm{A}}$ が $1.0 \sim 1.5$ の間の各区間においてもプロットが $98 \%$ 以上 包含されるように(5) 式の係数 $a, b, c$ を同定し, 同定した包絡線を 図 14(a) に併記する. (5) 式の各係数と ${ }_{e} D_{s}{ }^{\mathrm{A}}$ 值の関係を簡便化するた めに, 図 14(a) で同定した係数のうち $a$ と $b$ を一定とし, $c$ のみ変化 することで ${ }_{e} D_{s}^{\mathrm{A}}$ 值別の包絡線を求め, 図 $14(\mathrm{~b}) \sim(\mathrm{f})$ に併記する. そ の結果, $C O F^{\mathrm{A}}$ が 1.0 以上の各区間では包絡線がプロットの $98 \%$ 以 上包含しているのに対して, $C O F^{\mathrm{A}}$ が 1.0 より小さい範囲では包絡 線がプロットの $98 \%$ を包含できない区間がある。しかしながら，梁 が先行して降伏するために $C O F^{\mathrm{A}}$ を 1.0 以上にする必要があり, 図 14 に示した必要柱梁耐力比の包絡線が実際の設計に適用できると考 えられる.

${ }_{e} D_{s}^{\mathrm{A}}$ 值別の包絡線の各係数を図 15 に示寸. (5) 式の係数のうち $c$ を(6) 式で近似し，図 15 に ${ }_{e} D_{s}^{\mathrm{A}}$ 值との関係を同定した結果を併記す る.ただし， $c_{1}$ と $c_{2}$ は (6) 式の係数である.

$$
c=c_{1} \cdot{ }_{e} D_{s}+c_{2}
$$

(6) 式を (5) 式に代入すれば, 入力方向の ${ }_{e} D_{s}{ }^{\mathrm{A}}$ 值と必要な $C O F^{\mathrm{A}}$ の 関係式が得られる. 構面方向入時, $C O F^{\mathrm{A}}$ が構面方向の柱梁耐力比 $C O F,{ }_{e} D_{s}{ }^{\mathrm{A}}$ 值が構面方向の構造特性係数相当值 ${ }_{e} D_{s}$ と同一となり, 構面方向の必要な柱梁耐力比を (7) 式で表す.

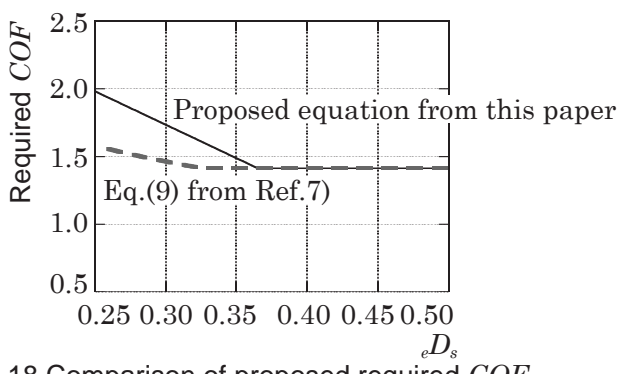

Fig.18 Comparison of proposed required $\mathrm{COF}$

$$
C O F=\max \left\{1, \frac{a}{\Sigma \theta_{p} / \theta_{u p}+b}+c_{1 e} D_{s}+c_{2}\right\}
$$

ここで，骨組の平面形状などによって直交 2 方向の構面耐力が異 なり，骨組の $C O F^{\mathrm{A}}$ の平均值が最も小さくなる方向が必ずしも $45^{\circ}$ 方向とは限らないが，節点レベルで考えると，直交 2 方向の梁耐力 が同程度であれば， $45^{\circ}$ 方向の $C O F^{\mathrm{A}}$ が最も小さくなる. 本論文の 対象骨組においても, 平面形状と関係なく直交 2 方向の梁耐力が同 程度となる節点が多く存在している. そのため, 本論文では構面方 向と $45^{\circ}$ 方向入力を考慮した構面方向における必要な節点ごとの柱 梁耐力比を検討する.

骨組の $45^{\circ}$ 方向の ${ }_{e} D_{s}{ }^{\mathrm{A}}$ 值が構面方向の構造特性係数相当值 ${ }_{e} D_{s}$ の $\sqrt{2}$ 倍, 構面方向の柱梁耐力比 $C O F$ が $45^{\circ}$ 方向の $C O F^{\mathrm{A}} の \sqrt{2}$ 倍とし, $45^{\circ}$ 方向入力時の構面方向の必要な柱梁耐力比を (8) 式で表す.

$$
C O F=\sqrt{2} \cdot \max \left\{1, \frac{a}{\Sigma \theta_{p} / \theta_{u p}+b}+c_{1} \sqrt{2}{ }_{e} D_{s}+c_{2}\right\}
$$

ただし，COF ${ }^{\mathrm{A}}$ が 1.0 より小さくなると，柱が梁より先行して降伏 するため, 入力方向の $C O F^{\mathrm{A}}$ が 1.0 以上となるように (7) 式と (8) 式 を設定している.

柱端の累積塑性変形 $\Sigma \theta_{p}$ を $\theta_{u p}$ 以下に留めるため, $\Sigma \theta_{p} / \theta_{u p}$ を 1 と し, 構面方向の必要柱梁耐力比を算定する. ${ }_{e} D_{s}$ 值に対して (7) 式と (8) 式のうち大きい方を必要柱梁耐力比とし, 図 16 の実線となる.

以上が FA ランクの部材を用いて柱端の累積塑性変形 $\Sigma \theta_{p}$ を $\theta_{u p}$ 以 下に留めるための必要柱梁耐力比の検討である. FB と FCランクの 部材を用いた場合に対してもFA ランクと同様に信頼性指標 2 を基 準にとり, 図 14 と図 15 の方法で包絡線を求める. 得られた幅厚比 ランク別の必要柱梁耐力比を図 17 に示し，(7) 式と (8) 式の各係数を 表 3 にまとめる.

図 17 より，FA ランクの柱を用いた場合， ${ }_{e} D_{s}$ 值が 0.35 以上，必 要柱梁耐力比が 1.5 以下となる. そのため鋼構造ラーメンの ${ }_{e} D_{s}$ 值が 0.35 以上で, 柱梁耐力比が現行の耐震規定の 1.5 を満たせば, 柱の 損傷を保有性能以下に留めることができる．FBランクの柱を用いた 場合 ${ }_{e} D_{s}$ 值が 0.40 以上, $\mathrm{FC}$ ランクの柱を用いた場合 ${ }_{e} D_{s}$ 值が 0.47 以上で, 柱梁耐力比が現行の耐震規定を満たせば，柱の損傷を保有 性能以下に留めることができる.

\section{4 既往の研究との比較}

構造特性係数相当值 ${ }_{e} D_{s}$ と必要柱梁耐力比の関係について, 小川ら の提案式 ${ }^{7)}$ と本論文の提案式と比較する. 小川らは直交 2 方向構面 の梁の耐力が等しい中低層鋼構造骨組に対して特定層の変形集中を 抑制するために必要な柱梁耐力比を (9) 式として導いてる. $V_{\mathrm{dm}}$ は損 傷に寄与する地震入力エネルギーの速度換算值である。

$$
C O F=\sqrt{2} \cdot \max \left\{1,0.5+0.6 V_{d m}\left(\frac{0.3}{\sqrt{2_{e}} D_{s}}\right)-0.09 V_{d m}^{2}\left(\frac{0.3}{\sqrt{2}{ }_{e} D_{s}}\right)^{2}\right\}
$$

本論で求めた FA ランクの提案式と (9) 式を図 18 に示し, 比較する. ただし， $V_{\mathrm{dm}}=1.5 \mathrm{~m} / \mathrm{s}$ とする. 図 18 より, ${ }_{e} D_{s}$ 值が小さい範囲で本論 文の提案式が小川らの提案式より大きくなっている.

本論文と異なり, 小川らは魚骨骨組を用いているため, フロア内の 柱梁耐力比分布の影響を考慮していない. また，小川らは (2) 式の最 適分布と同様となるように梁の耐力分布が設定しているのに対して, 
本論文では梁耐力和を調整した 4 層 6-6-1 と 4 層 6-8-3 の $0^{\circ}$ 方向と 4 層 6-6-3A を除けば, 骨組の梁耐力和の高さ方向分布は必 ずしも (2) 式の分布と完全に一致するとは限らない。このように, 実 際の設計で起こりうるフロア内の柱梁耐力比分布の不均等や梁耐力 和の高さ方向分布の影響によって, 図 18 の差が生まれたと考えられ る.

\section{5. 結論}

角形鋼管柱を有する鋼構造立体骨組を対象に，骨組の柱梁耐力比， 層数, 平面形状と入力地震動の入力波, 入力方向をパラメータとし た前報 ${ }^{5)}$ に引き続き, 構造特性係数相当值を新たなパラメータに追 加し，立体骨組モデルによる時刻歴応答解析を行い，柱の損傷を抑 えるために必要な柱梁耐力比を，2次設計レベルの入力に対して検討 した。得られた知見を以下に示寸。

[1] 見かけの構造特性係数相当值 ${ }_{e} D_{s}^{\mathrm{A}}$ が大きくなると，1 層柱頭以 上の部材端の塑性変形による消費エネルギーが減少し, 減少した分 のエネルギーが 1 層柱脚に集中する

[2] 梁耐力の高さ方向分布により, 層の反曲点高さが柱脚側に移行し, 柱頭の柱梁耐力比が大きくても損傷が大きくなる場合がある. 文献 8) で提案された部材強度分布に従えば，柱端の損傷が柱梁耐力比に大 きく依存するようになる.

[3] 梁耐力分布が概ね文献 8) の提案式に従い, ${ }_{e} D_{s}{ }^{\mathrm{A}}$ 值が同程度であ れば, 柱端の等価な累積塑性回転角 $\Sigma \theta_{p}$ と見かけの柱梁耐力比 $C O F^{\mathrm{A}}$ の関係は骨組の層数や平面形状，地震動の入力方向によらずほぼ同 様の傾向を示寸

［4］ $\Sigma \theta_{p}$ を角形鋼管柱の保有変形性能 $\theta_{u p}$ で無次元化した值の分布を ガンマ分布の確率密度関数で表すことができる

［5］信頼性指標 2 を基準に柱の幅厚比ランクと構面方向の構造特性 係数相当值 ${ }_{e} D_{s}$ に応じた構面方向の必要柱梁耐力比の分布を求めた. $\mathrm{FA}$ ランクの柱を用いた場合, ${ }_{e} D_{s}$ 值が 0.35 以上で, 柱梁耐力比が現 行の耐震規定を満たせば，柱の損傷を保有性能以下に留めることが できる.

なお，上述の知見は 2 次設計レベルの入力を受ける偏心のない中 低層ラーメンに有効である。ただし，本論文では入力レベル（損傷 に寄与する地震入力エネルギーの速度換算值 $V_{\mathrm{dm}}$ ) を一定にし，骨組 の保有水平耐力（見かけの構造特性係数相当值 ${ }_{e} D_{s}{ }^{\mathrm{A}}$ ) をパラメータ としているが, ${ }_{e} D_{s}{ }^{\mathrm{A}}$ 值を一定にし,$V_{\mathrm{dm}}$ をパラメータとした解析とは 同義と考えられる．また，本論では柱脚形式の影響，柱梁接合部パ ネルの挙動や合成梁の効果を考慮していない。これらの影響につい ては今後の課題とする.

\section{謝辞}

本論の著者である吹田啓一郎先生（京都大学・教授）は，2016 年 6 月 5 日に逝去されました。謹んでご冥福をお祈りするとともに，生 前のご指導に深甚なる感謝の意を捧げます.

\section{参考文献}

1) 坂本順, 小浜芳朗 : 静的崩壊機構特性と動的応答性状について, 日本建築 学会大会学術講演梗概集, 構造系第 49 号, pp.963-964, 1974.8

2) 加藤勉, 秋山宏 : 強震による構造物へのエネルギ入力と構造物の損傷, 日 本建築学会論文報告集, 第 235 号, pp.9-18, 1975.9
3) 国土交通省国土技術政策総合研究所, 国立研究開発法人建築研究所 : 2015 年版 建築物の構造関係技術基準解説書，2015.6

4) 独立行政法人建築研究所 : 2008 年版 冷間成形角形鋼管設計・施工マニュ アル, 2008.12

5) 陳逸鴻, 聲高裕治, 吹田啓一郎：角形鋼管柱を有する鋼構造立体骨組の地 震応答に及ぼす入力方向と柱梁耐力比の影響, 日本建築学会構造系論文集, 第 717 号, pp.1773-1783，2015.11

6) 長谷川隆，山内泰之：強震時における中低層鋼構造骨組の損傷分布に基 づく部材の必要塑性変形能力, 日本建築学会構造系論文集, 第 460 号, pp.169-177, 1994.6

7) 酒井快典, 小川厚治：水平 2 方向地動を受ける鋼構造骨組の適正な柱梁 耐力比日本鋼構造協会鋼構造論文集，第 17 巻，第 67 号, pp.53-64, 2010.9

8) 川島敏夫，出口義史，小川厚治 : 鋼構造骨組の部材耐力分布の適正化に関 する研究，日本建築学会構造系論文集，第 635 号，pp.147-155，2009.1 


\title{
EFFECTS OF HORIZONTAL LOAD BEARING CAPACITY ON REQUIRED COLUMN OVERDESIGN FACTOR OF 3D STEEL MOMENT FRAMES WITH SQUARE TUBE COLUMNS
}

\author{
Iathong CHAN*, Yuji KOETAKA** and Keiichiro SUITA*** \\ ${ }^{*}$ Grad. Stud., Dept. of Architecture and Architectural Engineering, Kyoto Univ., M.Eng. \\ ** Assoc. Prof., Dept. of Architecture and Architectural Engineering, Kyoto Univ., Dr.Eng. \\ *** Prof., Dept. of Architecture and Architectural Engineering, Kyoto Univ., Dr.Eng.
}

Steel moment frames are designed to ensure sufficient energy absorption capacity by achieving an entire beam-hinging collapse mechanism against severe earthquakes. Therefore, the column overdesign factor is stipulated in seismic design codes. For example in Japanese seismic design code, the specified column overdesign factor is 1.5 or more for steel moment frames with square tube columns.

The previous study ${ }^{5)}$ described the results of the earthquake response analysis of $3 \mathrm{D}$ steel moment frames, and presented seismic demand for the column overdesign factor, depending on input direction and width-thickness ratio of columns, in order to keep the damage below the limit of plastic deformation of square tube columns. However, the horizontal load bearing capacity of the target frames was not adjusted, so that it remained the same value as the original frames had, and was different depending on the frame and direction. Since the higher the horizontal load bearing capacity of the frame the less plastic deformation response during earthquakes can be assumed, the effects of horizontal load bearing capacity on plastic deformation response and required column overdesign factor are not studied well enough in the previous study).

Therefore, this paper considers ${ }_{e} D_{s}^{\mathrm{A}}$, which is the coefficient proportional to horizontal load bearing capacity of frames, as a new parameter for the earthquake response analysis of 3D steel moment frames, and redefines the seismic demand for the column overdesign factor, depending on ${ }_{e} D_{s}^{\mathrm{A}}$ and width-thickness ratio of columns to keep the damage of square tube columns below the specified limit of plastic deformation. In addition to ${ }_{e} D_{s}^{\mathrm{A}}$, the major parameters adopted are column overdesign factor of beam-column connections, number of stories as shown in Fig.1, floor planes of frames as shown in Fig.2, and input direction of ground motions.

From Fig.5, which shows the sum of the members' Dissipation energy during earthquakes in every floor, the larger the horizontal load bearing capacity the more damage is suffered by the column bases of the 1st story, but less damage is suffered by other member ends. In this paper, apparent column overdesign factor $C O F^{\mathrm{A}}$ is defined as the ratio of plastic moment of the column(s) to the plastic moment of the beam(s) projected in the input direction of the ground motion, while column overdesign factor $C O F$ is of in-plane direction. As a result of earthquake response analysis, the relationships between cumulative plastic deformation $\Sigma \theta_{p}$ of column ends and $C O F^{\mathrm{A}}$ are shown as Fig.7 and Fig.11. From these figures, with the distribution of the sum of beam strength in every floor similar to Eq. (2) and the similar ${ }_{e} D_{s}^{\mathrm{A}}$, the profile of maximum value of $\Sigma \theta_{p}$ to $C O F^{\mathrm{A}}$ are almost identical regardless of number of stories, floor plan, and input direction of ground motion.

The plastic deformation capacity $\theta_{u p}$ of square tube columns depending on local buckling is adopted for different rank of width-thickness ratio as an index to evaluate the damage to columns. Hence, the ratio of $\Sigma \theta_{p}$ to $\theta_{u p}$ is indicated in the ordinates of Fig.12-14. The required $C O F^{\mathrm{A}}$ can be evaluated with a reliability index of 2 by drawing a 98 percentile envelope curve. The envelope curves in Fig.14 show the required $C O F^{\mathrm{A}}$ to keep $\Sigma \theta_{p} / \theta_{u p}$ below the specified value under reliability index of 2 for different ${ }_{e} D_{s}^{\mathrm{A}}$. Eq.(7), Eq(8) and Fig.17 show the relationship between ${ }_{e} D_{s}^{\mathrm{A}}$ and the required $C O F$ of in-plan direction to keep the cumulative plastic deformation below the limit of plastic deformation. From Fig.17, while ${ }_{e} D_{s}{ }^{\mathrm{A}}$ is more than 0.35 , the required $C O F$ is 1.5 with columns of FA rank width-thickness ratio. 